\title{
Analysis on the Export Effect of Chinese Enterprises' OFDI
}

\author{
Yunxiu Qiu ${ }^{1}$ \\ ${ }^{1}$ School of Economics and Management, Shandong Youth University of Political Science, Jinan 250103, China
}

\begin{abstract}
With the development of the world economy, in order to solve the fierce market competition between countries, one of the effective means for Chinese enterprises is foreign direct investment. The Chinese government requires continuous deepening of reforms, so there are more and more foreign direct investments by Chinese companies. In view of this situation, this paper focuses on the research of the export effect theory of Chinese enterprises' foreign direct investment. At the level of empirical testing, this paper separately analyzes China's total export trade as explained variables, foreign direct investment as explanatory variables, GDP as the control variable, establishes a relevant model to study the direct foreign investment of Chinese enterprises to China's exports. After testing the model, the trade effect is further analyzed. This thesis focuses on the theory of export effects, and in theoretical community will further improve the research on the foreign direct investment about Chinese enterprises, and put forward suggestions that can provide you with reference for related work.
\end{abstract}

\section{Introduction}

Effective foreign direct investment and improvement of foreign trade are important forms and means for governments and enterprises to develop the economy and actively participate in economic globalization. Economic war is a war without smoke. Nowadays, the world market is becoming more and more transparent, and it is more and more difficult to gain advantages in the Commodity Exchange in the world market by using information asymmetry. Although China is a country with the whole industrial chain, it mainly exports labor-intensive low value-added commodities, and the price has become the competitive edge. However, under the encircling-off of anti-dumping and various trade barriers, the competitive advantage is gradually weakened.

This paper holds that the operation of enterprises is a process of constant pursuit of high profits low-cost, frequently blocked, Chinese enterprises in foreign trade practice are treading on thin ice in the export market, in response to the buyers to negotiate with their rivals on price, Chinese enterprises foreign direct investment seems to be the effective means to solve this problem. Under the guidance and support of the "go global" policy of the Chinese government and supported by the strong economic strength, Chinese enterprises have made unimaginable progress in their OFDI. Looking back on the years that Chinese enterprises have gone through, the of DI of Chinese enterprises continues to grow at a high speed. According to the statistics from multiple departments, the OFDI of Chinese enterprises reached 807.95 billion yuan in 2019 , which also played a positive role in promoting the development of China's economy. At the same time, the export effects of the growing OFDI of
Chinese enterprises have become the focus of scholars and the government.

\section{Literature Review}

\subsection{Review of Domestic Research}

Based on the existing literature, Gu Xuesong [1], from the perspective of the difference in industrial structure, found that OFDI had a significant effect on the promotion of exports, and with the continuously differentiated industrial structure between China and the host country, the promotion effect would be constantly enhanced. Lin Zhifan [2] found that the performance of China's OFDI to developed and developing countries is different, with the former as export substitution effect and the latter as export promotion effect. Yan Zhoufu, Li Ru and Wu Fangwei [3], from the perspective of enterprise heterogeneity, concluded that Chinese enterprises' OFDI plays a significant role in promoting enterprises' exports, but its promotion effect is still different according to different investment modes. Vanadio Li and Linxia Sun [4], taking China's fdi strategy as the research content, said that investment strategy should be combined with the economic development level of different regions, and targeted measures should be taken for different development levels. Huang Guangqun [5] found that the influence of the scale and structure of OFDI and international trade is dialectical. Zhang Qianyu [6] pointed out through research that the host country has certain trade creation effect in the process of introducing Chinese direct investment, and the ofDI of Chinese enterprises is related to the development level of the host country. 


\subsection{Review of Foreign Research}

In order to ensure the related theory of comprehensive study abroad also is we need to refer to, in 1957, walter mondale replacement model is proposed for trade and investment is recognized as the classical economics theory, in the real economy, scholars found that the model and the direct investment of the substitution effect of international trade have bigger difference, so a lot of economists have different views on this. Pavis assumed that the production functions of the two countries were different, which meant that he relaxed the assumptions of Mundell's model. The existence of a complementary relationship between OFDI and foreign trade of the investing country became his official conclusion. Over time, Xiaoxiao Qing [7] incorporated capital, human resources and other macroeconomic factors into the study of OFDI. Lipsey and Wiess took the United States as the research object and started from the export of the industrial sector and the single parent company [8], and found that the complementary relationship existed between the export of the United States and foreign production. Lipsey, Ramstetter and Blomsstrom [9] discussed and analyzed the relationship between OFDI and export by studying the United States, Sweden and Japan. Lipsey and Ramstetter [10] analyzed and studied the industrial development status of Japan and the United States, and found that the employment status of the host country had a positive impact on Japanese exports, and would replace Japanese investment in a certain market in the United States. Kozo Kiyota and Shujiro Urata [11] empirically tested the influence of multinational enterprises on Japan's foreign trade based on Japan's trade and FDI data from 1994 to 2000 , and there was a certain control phenomenon.

\section{Models and Data}

\subsection{Models}

To ensure effective regression results, logarithms of relevant variable data were taken in this paper to establish a model. The econometric model is as follows:

$$
\text { Inex }=\beta_{1} \text { Inofdi }+\beta_{2} \text { Ingdp }+e_{t}+\alpha_{1}
$$

China's export trade is Inex, Chinese enterprises foreign direct investment is ofdi, China's gross domestic product is GDP. Random disturbance is et, a 1 is the constant term. In the following research, if the $\beta 1$ result is positive, it means that the export effect of Chinese enterprises' OFDI is positive, and Chinese enterprises' OFDI will play a positive role in promoting China's exports; otherwise, it indicates that Chinese enterprises' OFDI has substitution effect with China's exports.

\subsection{Variable Selection}

Chinese economists have fully studied the export effect. According to theoretical literature, the export effect has been clearly divided into four types, namely substitution effect, transfer effect, induction effect and market enlargement effect. Among these effects, the export substitution effect is manifested as the decrease of domestic export of the same products caused by enterprises' outward direct investment in producing the same products. Direct investment enterprises in the destination country produce the same kind product, likely imitated by investor in the enterprise in the production of this product, this kind of phenomenon is unaffected by the investor competition enterprise's scale, when the investor competitive enterprise on a smaller scale is big, the production of imitation products may only appear in the recipient countries market, but when be investor in the enterprise scale, the production of imitation products may flow in the international market. At the same time, with the continuous expansion of enterprise investment scale, mature operation of production base and reduction of management cost, the products invested and produced in the invested country will also play a substitute role for the products produced by domestic enterprises. Therefore, the export substitution effect indicates that the OFDI of enterprises is negatively correlated with the export volume of the home country. Transfer effect in imported mainly aimed at the host country, export enterprise direct investment for the host country, because of other factors such as distance, in the host country of raw materials or equipment purchase cost far more than the enterprise directly from the home supply of low cost and investment enterprises to reduce production cost so as to choose in direct investment destination countries or neighboring countries to purchase raw materials or equipment needed for production, will be his or her home country exports to reduce the related production data. Therefore, the effect of export transfer indicates that the OFDI of enterprises is negatively correlated with the export volume of the home country. The motherland enterprise in export cause effect on investment destination countries directly for commercial behavior, will give preference to foreign direct investment enterprises import business from home country needed raw materials, machinery and equipment, such as production, side led exports in the home country related industry, so the creation effect also is become export cause effect. Enterprise of foreign direct investment belong to long-term international capital flow behavior, different from general production flow, its early will form the huge production requirements, and the means of production demand generally provided by the original home to foreign direct investment enterprises supply chain, so that to pull his or her home country related industry exports have positive role in promoting. Therefore, the export induced effect indicates that the OFDI of enterprises is positively correlated with the export volume of the home country. Market expansion effect on foreign direct investment enterprises in the investment destination countries complementary products in the company's products produced, the complementary products can also be referred to as foreign investment enterprises in the destination country produces products home country of the final product, destination market will be invested enterprises produced products and increase the demand for home country of complementary products. In order to obtain the customer satisfaction of their products in the destination market, OFDI enterprises may need a variety of complementary products. However, their 
complementary products cannot be normally produced or meet their demand in the destination country of investment, so they need to import from the home country, thus increasing the export volume of their complementary products. In essence, the market expansion effect is an indirect effect. For this reason, the market expansion effect indicates that the OFDI of enterprises is positively correlated with the export volume of the home country.

The export of Chinese enterprises foreign direct investment effect should also apply to the above four kinds of effect, which is the net effect of the four also should be the export trade, therefore, the export of Chinese enterprises foreign direct investment has both positive and negative effect, by building a model to test analysis, this article selects is China's export trade as the explained variable, select Chinese enterprises foreign direct investment as the explained variable, select gross domestic product (GDP) as control variable, set up random disturbance and constant, to study the Chinese enterprise foreign direct investment effect of export trade in China.

\subsection{Data}

Historical data of China's total outbound direct investment, China's GDP and China's export trade from 2005 to 2019 are used as data support for empirical analysis. Data of China over the years required for this model. Data of China's OFDI are obtained from Statistical Bulletin of China's OFDI issued by ministry of Commerce of the People's Republic of China. The GDP data are from the China Statistical Yearbook published by the National Bureau of Statistics, PRC; Data on China's export volume are from the Commerce Data Center of the Ministry of Commerce, PRC.

\section{Empirical Analysis}

\subsection{Model Testing and Estimation}

\subsubsection{Stationarity Test}

The importance of stationarity tests is to avoid false regression. Through further analysis of the data, it can be found that China's foreign direct investment, China's export volume and China's GDP will continue to grow with the increasing strength of China's economy. Therefore, this paper tests the stability of these three groups of data and USES the econometric analysis tool Eviews 7.2. Table 1 shows the stationarity test results of the three groups of data:

Table1. Table Type Styles

\begin{tabular}{|c|c|c|c|c|}
\hline Variable & ADF test value & P value & $\begin{array}{c}\text { The critical value of } \\
5 \%\end{array}$ & Conclusion \\
\hline Inex & -2.752870 & 0.0902 & -3.098896 & Not Smooth \\
\hline DInex & -3.361231 & 0.0332 & -3.119910 & Smooth \\
\hline Inofdi & -3.707256 & 0.0170 & -3.098896 & Smooth \\
\hline Ingdp & -4.227419 & 0.0067 & -3.098896 & Smooth \\
\hline
\end{tabular}

According to ADF test results, the data of it Inex self is not a stationary time series, but after processing the data with first-order variance, it becomes a stationary time series, and the sequence of Inofdi and Ingdp shows a stationary trend.

\subsubsection{Cointegration Test}

According to the theoretical knowledge of econometrics, Inex, Inofdi and Ingdp are all first-order integral series. In order to further verify the stable relationship between these three groups of data, this paper USES Eviews7.2, an econometric tool, to conduct the following co-integration test on the data. Table 2 shows the co-integration test results of the three groups of data:

Table2. Co-integration test results

\begin{tabular}{|c|c|c|c|}
\hline Variable & $\begin{array}{c}\text { Estimated parameter } \\
\text { value }\end{array}$ & $\mathrm{t}$ value & $\mathrm{p}$ value \\
\hline $\mathrm{C}$ & 2.747650 & 1.931725 & 0.0773 \\
\hline Inofdi & 0.158940 & 1.571003 & 0.1422 \\
\hline Ingdp & 0.454712 & 2.923564 & 0.0128 \\
\hline
\end{tabular}

The regression model should be: Inex $=0.158940$ Inofdi +0.454712 Ingdp + et +2.747650 (2)

Based on the judgment of econometrics theory, the unit root test obtained the result that the mean value of the residual series was 0 . In order to verify the significance level of these three groups of data, the ADF test in the next stage was carried out (Table 3 ).

Table3. ADF inspection results

\begin{tabular}{|c|c|c|c|c|}
\hline \multicolumn{2}{|c|}{} & T Value & P Value \\
\hline \multicolumn{2}{|c|}{ ADF Statistics } & -3.42425 & 0.0003 \\
\hline \multirow{3}{*}{$\begin{array}{c}\text { Significance } \\
\text { level }\end{array}$} & $1 \%$ & & -2.459834 & \\
\cline { 2 - 2 } Theshold test & -1.664593 & \\
\cline { 2 - 2 } & $10 \%$ & & -1.534982 & \\
\hline
\end{tabular}

The test results show that the ADF value of the residual series is -3.42425 . In theoretical knowledge, if the data is significant at $1 \%$ significance level, the statistical $t$ value should be less than -2.459834 and -3.42425 less than 2.459834 , which fully indicates that the residual series is stable, so there is a co-integration relationship between Inex, Inofdi and Ingdp.

\subsubsection{Granger Causality Test}

According to the results of the co-integration test, there is a long-term and stable relationship between China's OFDI, total export trade and China's GDP. Therefore, according to econometrics theories, it is necessary to use Granger causality test to conduct the following tests on these three sets of data (Table 4).

Table4. Granger causality test results

\begin{tabular}{|c|l|c|c|c|}
\hline $\begin{array}{c}\text { Lag } \\
\text { phase }\end{array}$ & \multicolumn{1}{|c|}{ Null Hypothesis } & F value & P value & Results \\
\hline 4 & $\begin{array}{l}\text { ex is not the cause of the } \\
\text { change in ofdi }\end{array}$ & 9.9768 & $9 \mathrm{e}^{-5}$ & Refused \\
\hline
\end{tabular}




\begin{tabular}{|l|l|c|c|c|}
\hline & $\begin{array}{l}\text { ofdi is not the cause of } \\
\text { the change in ex }\end{array}$ & 8.7956 & 0.0003 & Refused \\
\cline { 2 - 5 } & $\begin{array}{l}\text { gdp is not the cause of } \\
\text { the change in ex }\end{array}$ & 10.0534 & $3 \mathrm{e}^{-5}$ & Refused \\
\cline { 2 - 5 } & $\begin{array}{l}\text { ex is not the cause of the } \\
\text { change in gdp }\end{array}$ & 8.7438 & 0.0005 & Refused \\
\cline { 2 - 5 } & $\begin{array}{l}\text { ofdi is not the cause of } \\
\text { the change in gdp }\end{array}$ & 8.7956 & 0.0001 & Refused \\
\hline $\begin{array}{l}\text { gdp is not the cause of } \\
\text { the change in ofdi }\end{array}$ & 13.8957 & $5 \mathrm{e}^{-5}$ & Refused \\
\hline
\end{tabular}

\subsection{The Model Results}

From the results of empirical test, stationarity test means that Inex data becomes stationary time series after processing with first-order variance, and Inofdi and Ingdp are stationary time series in themselves. In the following co-integration test, the ADF value of the residual series is -3.42425 , which is less than the statistical value $T$ value at the significance level of $1 \%$. Therefore, the three groups of data selected have a co-integration relationship and the residual series is stable. In the following Granger causality test, the result shows that the null hypothesis is rejected when the lag period is 4 , and the $\mathrm{p}$ value obtained is less than the corresponding value at the significant level of $5 \%$. Therefore, it can be said that there is a causal relationship between China's FDI, China's total export trade and China's GDP.

From the regression model, $\beta 1=0.158940$. The empirical test results fully demonstrate that the effect of OfDI of Chinese enterprises on China's export is positive, that is, the final result of the four effects of export effect is positive net value. However, it also shows that China's OFDI does not have a particularly strong driving effect on China's exports, which needs to be explained from the current situation of China's various aspects.

\section{Conclusion}

(1) Chinese enterprises' OFDI has a positive export effect

In the empirical test, $\beta 1$ obtained by regression of the model is positive, indicating that the export effect of OFDI of Chinese enterprises is positive, that is, Chinese enterprises' OFDI is positively correlated with China's exports. OFDI affects the scale and structure of China's export trade. Although OFDI does not affect the quality and structure of China's export trade in this study, it is bound to affect the international competitiveness of China's export products according to the export effect theory. However, from an empirical point of view, the impact of OFDI of Chinese enterprises on export effect is weak, perhaps because OFDI of Chinese enterprises is still in the development stage, and its size and scale need to be developed.

(2) There is a causal relationship between China's foreign direct investment and China's total export trade

According to empirical test results, especially Granger causality test, there is a causal relationship among China's FDI, China's total export trade and GDP data. According to logic, there must be a causal relationship between China's foreign direct investment and China's total export trade. We continue to study the export effect theory is that cause effect said export enterprise of foreign direct investment and home country exports were positively correlated relationship, market expand outward foreign direct investment effect said businesses and home country exports were positively correlated, the other two effects are negative correlation, now that China's foreign direct investment and China's export trade also inevitable causal relation between the said two positive correlation of comprehensive effect, its strength is greater than the negative correlation between the two. It deeply shows that the development of China's OFDI is closely related to the export volume of China's general trade, and its influence is also significant. Therefore, OFDI of Chinese enterprises is also a tool to drive the export volume of China's general trade.

(3) Both OFDI of Chinese enterprises and the volume of China's export trade have been increasing steadily year by year

This paper also makes a comparative analysis of China's historical data. According to the data curve and various references, it also draws a conclusion that both ofDI of Chinese enterprises and China's export trade increase steadily year by year. Foreign direct investment and foreign trade is an important means of development of foreign economic around the world, China area and all the way walk out strategic remarkable achievements, although our country enterprise of foreign direct investment compared with the developed countries started late. However, with the strength of China's second largest economy and effective by the Chinese government economic policy, foreign direct investment has played an important role to the Chinese enterprise, which shows that the system of the socialism with Chinese special superiority.

\section{References}

1. Gu Xuesong, Han Liyan, Zhou Yimin. Industrial structure difference and export effect of ofdi -- theory and empirical study from the perspective of "China -host country" [J]. Economic research,2016,51(04):102-115.

2. Lin Zhifan. Does China's OFDI really promote exports [J]. Finance and Trade Economics,2016(02):100-113.

3. Yan Zhoufu, Li Ru, Wu Fangwei. Export effect of ofdi of Chinese enterprises -- an empirical study based on the perspective of enterprise heterogeneity [J]. Statistical research,2019,36(08):87-99.

4. Li V, Sun Linxia. Research on China's OFDI and Its Economic Driving Effect [J]. Shandong Social Sciences,2018(11):160-165.

5. Huang Guangqun. Analysis on export Effect of OfDI of Chinese Enterprises -- Empirical Analysis based on data from 2011 to 2018 [J]. Journal of Anyang Normal University,2019(03):36-39.

6. Zhang Qianyu. Study on the Trade Effect of China's OFDI [D]. Anhui University of Finance and Economics, 2017. 
7. Wang Y. Foreign trade theory [M]. Tianjin: Nankai University Press, 1978.

8. Robert E.Lipsey,and Merle Yahr Weiss,Foreign Production and exports in manufacturing industries,Review of economics and statistics, 1981,63.

9. Robert E.Lipsey,Eric Ramstetter,and Magnus Blomstrom, Outward FDI and Home Country Exports:Japan, the United States, and Sweden, SSEEFI WorkingPaper Series in Economics and Finance NO369, March 2000.

10. Robert E. Lipsey,Eric Ramstetter,Affiliate Activity in Japanese and U.S.Multinationals and Japanese Exports,1986- 1995, NBER Working Paper Series8581, November 2001.

11. Kozo Kiyota,Shujiro Urata,the Role of Multinational Firms in Intermational Trade:the Case of Japan,RIETID Discussion Paper Series 05-E012,March 2005. 